\title{
Protein Cereblon
}

National Cancer Institute

\section{Source}

National Cancer Institute. Protein Cereblon. NCI Thesaurus. Code C104142.

Protein cereblon (442 aa, $\sim 51 \mathrm{kDa}$ ) is encoded by the human CRBN gene. This protein plays a role in assembly and regulation of calcium-activated potassium channels in brain. 